\title{
SCARLET TANAGER AT JACKFISH LAKE, SASKATCHEWAN
}

DAVID H. WRIGHT, 222 Saskatchewan Crescent West, Saskatoon, Saskatchewan. S7M OA4

On 15 May 1985 I made my first visit to The Battlefords Provincial Park. The day was sunny and clear, with moderate breeze and a temperature of $18^{\circ} \mathrm{C}$. After entering the park at the north end I proceeded south-westerly on the main road on the north side of Jackfish Lake about $0.5 \mathrm{mi}$. and then turned off on a rough, winding trail that leads to the lake. After inspecting the beach area I returned to the spot where I had parked my car, near a clump of poplars and tall shrubbery. As I paused to look around I noticed what appeared to be several female Northern Orioles flitting quickly through the shrubbery. They were part of a flock of six to eight birds that moved off quickly to a large stand of poplars and shrubs to the west. As I watched them I noticed a brilliant scarlet bird, oriole-sized but chunkier in shape, perched on a dead limb at the top of the grove of trees. I was about 300 yards away and I quickly raised my binoculars to verify what I had seen. As the bird faced me I had a clear and totally unobstructed view for nearly a minute. It was a stunning sight - a male Scarlet Tanager! I was very familiar with the Cardinal and this specimen was smaller, had no crest and was a more brilliant scarlet. I had seen the Western Tanager many years before while birding with the late (and great) Maurice Street near Nipawin. I realised after about 10 seconds that another male was perched about $12 \mathrm{in}$. below and to the side of the first. He was turned away from me and it was easy to see the black wings and tail. Both males continued to perch in the bright spring light for about 15 seconds and then disappeared in a westerly direction.
I was a bit shaken by what I had seen since it was my first live observation of a Scarlet Tanager. When I later reported my sighting to Stuart Houston I learned that this is probably the most northwesterly sighting of this species in Saskatchewan. Whatever the significance to others it was a great thrill for me.

I noted that day also the following more prosaic species in the park: Yellow Warbler (quite common); Franklin's Gull (common); Common Crow (very common); Northern Oriole (common); Barn Swallow (very common, nesting under the eaves of a park building); Bank Swallow (common); Killdeer; flicker; Tree Swallow; Savannah Sparrow (common); Herring Gull (common); Mountain Bluebird (one male seen near the park gate). 